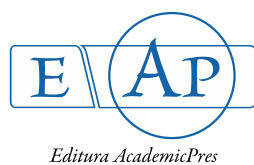

Editura AcademicPres

\title{
Assessment of the Water Quality of Saba River, Osogbo, Nigeria
}

\author{
Oluwafisayo A. YUSUF ${ }^{1}$, Henry A. ADEWOLE ${ }^{2 *}$, \\ Victor F. OLALEYE ${ }^{2}$ \\ ${ }^{1}$ Obafemi Awolowo University, Institute of Ecology and Environmental Studies, Ile-Ife, Nigeria; oluwafisayorichie@gmail.com \\ ${ }^{2}$ Obafemi Awolowo University, Department of Zoology, Ile-Ife, \\ Nigeria; hensaigebnnos_2k@yahoo.com (*correspondingauthor)olafoluwa_59@yahoo.com
}

\begin{abstract}
The water quality and concentrations of selected heavy metals (cadmium, lead, and zinc) in Saba River, Osogbo were assessed monthly over a period of six months with a view to providing information on the water quality of the potentially polluted urban river system. Three sampling sites were selected along the Saba River (the upper reach of the river (Station A), mid-point of the river (Station B) and the lower reach of the river where it emptied into River Osun (Station C)). The recorded ambient air and water temperature, $\mathrm{pH}$, alkalinity conductivity, total hardness, $\mathrm{BOD}$ and COD, as well as the phosphate and nitrate levels of Saba River, were within the maximum allowable regulatory limits of WHO (2011). The dissolved oxygen level between March and April in all the sampling points were in the limit of putting aquatic life under stress $(<5.0 \mathrm{mg} / \mathrm{L})$. Also the alkalinity level in station B between February and June, and in Station C from February till May were however above the maximum allowable desirable range of EPA (2001) and WHO (2011). The concentration of zinc, which ranged from 717 to $1,000 \mu \mathrm{g} / \mathrm{L}$, was the highest amongst the selected metals assayed in the water. However, the mean concentration of lead in the water samples collected from Stations B and C $(26 \mu \mathrm{g} / \mathrm{L}$ and $24 \mu \mathrm{g} / \mathrm{L}$, respectively) was found to be above recommended regulatory acceptable limits of $20 \mu \mathrm{g} / \mathrm{L}$ of WHO (2011) and FEPA (2007). The study concluded that the physico-chemical indices of the water quality indicated that the river was mildly polluted.
\end{abstract}

Keywords: heavy metal, pollution, Saba River, water quality

\section{Introduction}

Apart from natural influences which range from geological, hydrological and climatic factors (UNEP / WHO, 1996), population growth coupled with other factors such as urbanization, agricultural activities, industrial and commercial processes has resulted in the accumulation of wastes and pollutants that ends up in water bodies. Moreover, heavy metals which are natural trace components of the aquatic environment, as well as constitute of most hazardous substances that could be accumulated in the biota, may be discharged from industries, farmlands, municipal urban water run-offs and agricultural activities into water surface, thereby causing pollution (Butu et al., 2013). This has significant influence on the quality of water, species composition and biodiversity of many aquatic systems (Dike et al., 2004).

Water pollution directly or indirectly affects both terrestrial and aquatic life (Chapman and Kimstach, 1996; Gulson et al., 1997; Ogunfowokan et al., 2005; Duruibe et al., 2007; Lawson, 2011). This depends largely on the concentration of the pollutants, which is in turn determined by their degradation level and the volume of the receiving waterbody (Sterrit and Lester, 1998). Different indicators are the biochemical reactions within water systems which is a function of physico-chemical parameters such as temperature, $\mathrm{pH}$, dissolved oxygen, total dissolved solids, and nutrient loads (Gulson et al., 1997).

Studies have shown that most rivers flowing through heavily urbanized and industrialized areas in Nigeria are contaminated with high concentration of some metallic ions of variable and unsuitable physico-chemical characteristics (Peretiemo-Clarke et al., 2009). Osogbo, a south-western city in Nigeria is not heavily industrialised, however a lot of anthropogenic activities (indiscriminate dumping of refuse, defecating and erosion which washes agricultural residues like fertilizers into water bodies) impact the aquatic ecosystems. Therefore, assessment of the water quality and heavy metal load of Saba River which is a distributary of the Osun River located in a metropolitan 
town like Osogbo, and the potential risk of domestic use and the aquatic biota is very essential, hence the hereby investigation was undertaken.

\section{Materials and Methods}

\section{Description of study site}

Saba River is one of the small rivers in the Osogbo metropolis which has its source from a Lake named 264 located in the Saba community and empties into the Osun River in Osogbo. The river is located approximately within the Latitudes $07^{\circ} 79^{\prime} 96^{\prime \prime}$ to $07^{\circ} 77^{\prime} 84^{\prime \prime} \mathrm{N}$ and Longitude $004^{\circ} 56^{\prime} 22^{\prime \prime}$ to $004^{\circ} 54^{\prime} 03^{\prime \prime} \mathrm{E}$ (Fig. 1) and covered a distance of $5.20 \mathrm{~km}$ from its source to the point of discharge into River Osun. The river along its channel serves the purpose of irrigation for peasant vegetable and maize farmers and source of water into earthen ponds for fish culture. Mechanic workshops were also situated along the river bank, as well as a market community whose organic wastes are being disposed into the river.

Three sampling stations designated Stations A, B and C, were established along the river channel with the geographical points shown in Table 1 . Station A was located within the Saba community, about 200 meters to Lake 264. The sampling point was picked based on its accessibility and nearness to the Lake and it was an area devoid of municipal and domestic wastes. Station B was located almost at the mid-point of the river channel around Rasco where mechanic workshops were also situated, while Station C was located around Alekuwodo market just before the point of

Table 1. Geographical location of the sampled stations

\begin{tabular}{cccc}
\hline $\begin{array}{c}\text { Sampling } \\
\text { Points }\end{array}$ & Latitudes (N) & Longitudes (E) & Elevation (m) \\
\hline Station A & $07^{0} 79^{\prime} 64^{\prime \prime}$ & $04^{0} 56^{\prime} 2.1^{\prime \prime}$ & 423 \\
Station B & $07^{0} 78^{\prime} 20.7^{\prime \prime}$ & $04^{0} 54^{\prime} 75.4^{\prime}$ & 423 \\
Station C & $07^{0} 77^{\prime} 84.2^{\prime \prime}$ & $04^{0} 54^{\prime} 03.3^{\prime \prime}$ & 420 \\
\hline
\end{tabular}

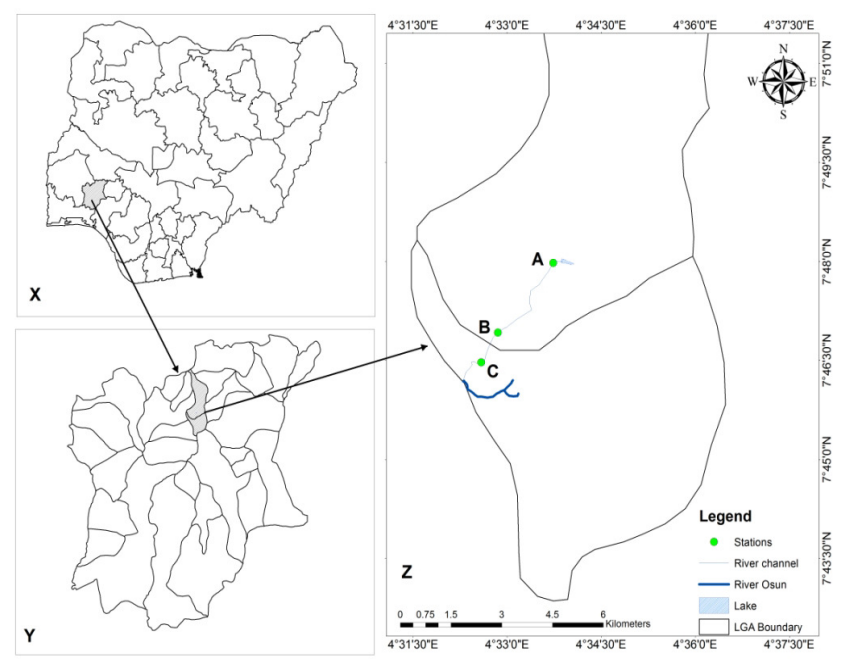

Fig. 1. (X) Map of Nigeria showing Osun State, (Y) Map of Osun State showing Osogbo and Olorunda Local Government Areas, $(\mathrm{Z})$ Map showing the Lake and the sampled stations on the Saba River entry of the river into the Osun River. About the midpoint of station $\mathrm{B}$ from $\mathrm{A}$ is a refuse dumping site, while between sampling stations $\mathrm{B}$ and $\mathrm{C}$ is the market dump site.

\section{Water sample collection}

Water samples were collected fortnightly at the surface level from the three selected sampling stations along the river channel for a period of six months between January and June, 2015 for the physico-chemical analysis and determination of the selected metallic ion concentration. Samples were collected in 21 sterilized plastic containers. During sampling, the containers were rinsed three times with sample water before filling with the samples. After collection, the samples were protected from direct sunlight and transported in a cooler box containing ice packs to the laboratory for analysis. All samples were stored at $4{ }^{\circ} \mathrm{C}$ and analysed within 48 hours of sample collection.

\section{Physicochemical water quality analysis}

Air and water temperature were determined in situ using mercury in glass thermometer, while multipurpose $\mathrm{pH} /$ ion meter was used to determine $\mathrm{pH}$, conductivity and TDS levels on the field. DO, BOD, COD, alkalinity, acidity and total hardness were determined using standard methods of Golterman (1978), Ademoroti (1996), APHA, AWWA and WEF (1992) as applicable. Phosphate and nitrate were determined using colorimetric methods, while the heavy metal concentration were determined using Atomic Absorption Spectophotometry (AAS).

Data on the water quality parameters and the metallic ion concentration of the water samples across the sampled stations were subjected to repeated measure analysis of variance (ANOVA) and Duncan's Post hoc Multiple test range as applicable using SPSS software package (Version 21).

\section{Results and Discussion}

\section{Temperature}

The mean monthly values of the water temperature varied between $25^{\circ} \mathrm{C}$ and $26.5 \pm 0.71{ }^{\circ} \mathrm{C}$ (Fig. 2). The variations in the ambient and water temperature between the three stations were found not to be significantly different $(\mathrm{P}>0.05)($ Table 2). An inconsistent variation pattern in the monthly mean water temperature value was observed across the sampling stations during the period of study (Fig. 2). However, water temperature values recorded

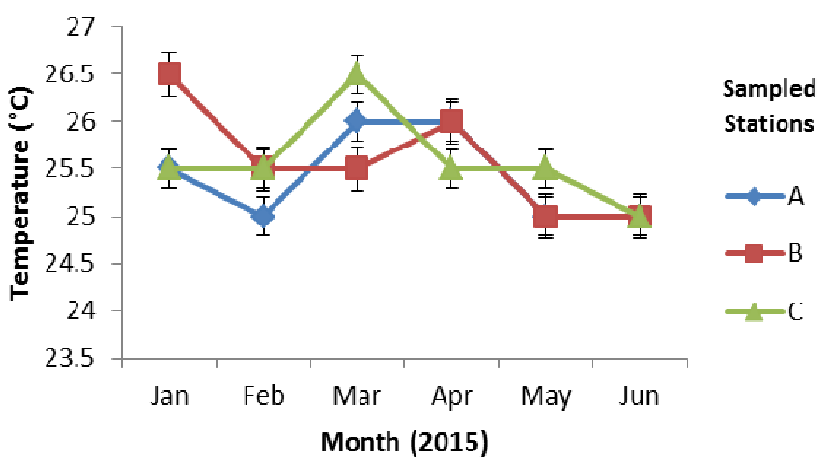

Fig. 2. The monthly mean variation of water temperature $\left({ }^{\circ} \mathrm{C}\right)$ of the water sampled from Saba River 
190

Table 2. Post-Hoc Multiple comparison (Duncan Multiple Range Test) to compare mean variations in physico-chemical and heavy metal parameters of the water across the sampling Stations

\begin{tabular}{|c|c|c|c|}
\hline Parameters & $\begin{array}{c}\text { Station A } \\
(\text { Mean } \pm \text { S.D })\end{array}$ & $\begin{array}{c}\text { Station B } \\
(\text { Mean } \pm \text { S.D })\end{array}$ & $\begin{array}{c}\text { Station C } \\
(\text { Mean } \pm \text { S.D })\end{array}$ \\
\hline Air Temperature $\left({ }^{\circ} \mathrm{C}\right)$ & $26.08 \pm 0.27^{a}$ & $26.25 \pm 0.27^{a}$ & $26.25 \pm 0.27^{a}$ \\
\hline Water Temperature $\left({ }^{\circ} \mathrm{C}\right)$ & $25.42 \pm 0.21^{a}$ & $25.58 \pm 0.21^{\mathrm{a}}$ & $25.67 \pm 0.21^{\mathrm{a}}$ \\
\hline Conductivity $(\mu \mathrm{S} / \mathrm{cm})$ & $291.27 \pm 19.44^{b}$ & $507.62 \pm 19.44^{a}$ & $482.85 \pm 19.44^{a}$ \\
\hline TDS (mg/L) & $183.92 \pm 7.07^{\mathrm{b}}$ & $303.17 \pm 7.07^{\mathrm{a}}$ & $288.17 \pm 2.07^{\mathrm{a}}$ \\
\hline $\mathrm{pH}$ & $7.36 \pm 0.28^{\mathrm{a}}$ & $7.30 \pm 0.28^{\mathrm{a}}$ & $7.58 \pm 0.28^{b}$ \\
\hline Hardness $\left(\mathrm{mg} / \mathrm{L} \mathrm{CaCO}_{3}\right)$ & $96.87 \pm 5.93^{b}$ & $155.31 \pm 5.93^{a}$ & $156.98 \pm 5.93^{a}$ \\
\hline Acidity $\left(\mathrm{mg} / \mathrm{LCaCO}_{3}\right)$ & $21.33 \pm 2.34^{\mathrm{a}}$ & $59.67 \pm 2.34^{b}$ & $39.50 \pm 2.34^{\mathrm{c}}$ \\
\hline Alkalinity $\left(\mathrm{mg} / \mathrm{L} \mathrm{CaCO}_{3}\right)$ & $120.17 \pm 4.96^{a}$ & $203.67 \pm 4.96^{\mathrm{b}}$ & $177.17 \pm 4.96^{\mathrm{c}}$ \\
\hline $\mathrm{DO}(\mathrm{mg} / \mathrm{L})$ & $6.70 \pm 0.48^{\mathrm{a}}$ & $6.60 \pm 0.48^{\mathrm{a}}$ & $6.20 \pm 0.48^{\mathrm{a}}$ \\
\hline $\mathrm{BOD}(\mathrm{mg} / \mathrm{L})$ & $6.43 \pm 0.44^{a}$ & $6.47 \pm 0.44^{a}$ & $6.73 \pm 0.44^{a}$ \\
\hline $\operatorname{COD}(\mathrm{mg} / \mathrm{L})$ & $19.70 \pm 0.99^{\mathrm{a}}$ & $24.28 \pm 0.99^{b}$ & $21.90 \pm 0.99^{\mathrm{ab}}$ \\
\hline Phosphate mg/L & $3.25 \pm 0.13^{\mathrm{a}}$ & $4.70 \pm 0.13^{b}$ & $3.03 \pm 0.13^{\mathrm{a}}$ \\
\hline Nitrate $\mathrm{mg} / \mathrm{L}$ & $1.92 \pm 0.13^{\mathrm{a}}$ & $2.86 \pm 0.13^{\mathrm{b}}$ & $1.67 \pm 0.13^{\mathrm{a}}$ \\
\hline Cadmium $(\mu \mathrm{g} / \mathrm{L})$ & $19.92 \pm 1.11^{b}$ & $27.33 \pm 1.11^{\mathrm{a}}$ & $25.17 \pm 1.11^{\mathrm{a}}$ \\
\hline Lead $(\mu \mathrm{g} / \mathrm{L})$ & $8.67 \pm 0.72^{b}$ & $27.00 \pm 0.72^{b}$ & $24.33 \pm 0.72^{b}$ \\
\hline $\operatorname{Zinc}(\mu \mathrm{g} / \mathrm{L})$ & $776.33 \pm 19.56^{\mathrm{b}}$ & $927.50 \pm 19.56^{\mathrm{a}}$ & $931.08 \pm 19.56^{a}$ \\
\hline Arsenic $(\mu \mathrm{g} / \mathrm{L})$ & $0.50 \pm 0.13^{\mathrm{b}}$ & $3.75 \pm 0.13^{\mathrm{b}}$ & $5.25 \pm 0.13^{\mathrm{b}}$ \\
\hline Chromium $(\mu \mathrm{g} / \mathrm{L})$ & $0.67 \pm 0.13^{\mathrm{b}}$ & $1.92 \pm 0.13^{\mathrm{a}}$ & $2.17 \pm 0.13^{\mathrm{a}}$ \\
\hline
\end{tabular}

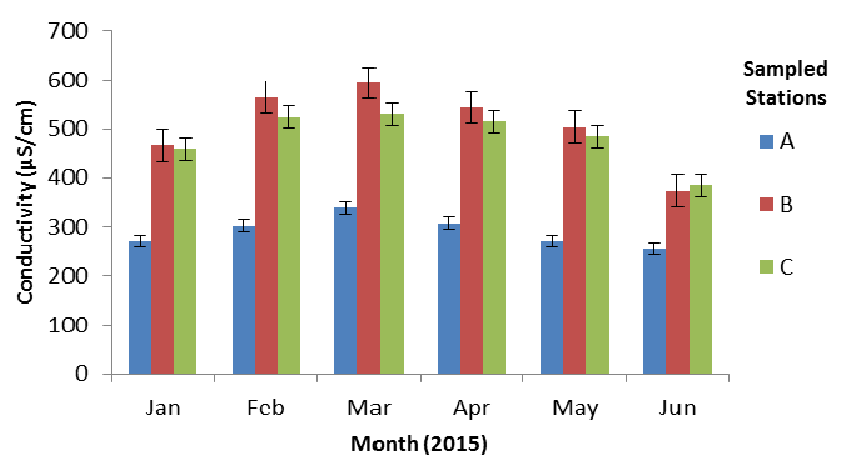

Fig. 3. The monthly mean variation of water conductivity $(\mu \mathrm{S} / \mathrm{cm})$ of the water sampled from Saba River

during the sampling period which ranged from $23.0{ }^{\circ} \mathrm{C}$ to $28.0^{\circ} \mathrm{C}$ fell within the optimal range values $21^{\circ} \mathrm{C}$ and $32^{\circ} \mathrm{C}$ recorded for several tropical freshwaters (Ayodele and Ajani, 1999; Ali, 2007; Shektia, 2008).

\section{Conductivity}

Conductivity is an index of the total ionic content of water and an indication of the freshness or otherwise of the water (Ogbeibu, 1991). Electrical conductivity values of $255.05 \mu \mathrm{S} / \mathrm{cm}$ to $593.60 \mu \mathrm{S} / \mathrm{cm}$ recorded in Saba River during the sampling period fell within the range of 10-1000 $\mu \mathrm{S} / \mathrm{cm}$ known for many African water bodies (Chapman and Kimstach, 1996). Throughout the period of study, irrespective of the month, conductivity level followed this order: Station B > Station C > Station A. However, conductivity level reached its peak in March 2015 (Fig. 3). The mean conductivity values of the water sampled from Stations B and C were not statistically different $(\mathrm{P}>0.05)$, but were statistically higher $(\mathrm{P}<0.005)$ than the mean conductivity of the water samples collected from station A (Table 2).

\section{Determination of $p H$}

The hydrogen ion concentration $(\mathrm{pH})$ of Saba River showed slight variations within the sampling period with the values ranging from near neutral to weakly alkaline (7.18 and 7.64). The highest mean $\mathrm{pH}$ value was recorded in March and May 2015 at Station C, while the lowest value was also recorded in March 2015 at sampling station B (Fig. 4). The $\mathrm{pH}$ values were within acceptable range (6.5 to 8.5 ) for most lakes, rivers and streams (Welch, 1952). The $\mathrm{pH}$ range recorded was equally similar to those recorded in some other Nigerian waterbodies (Onwudinjo, 1990; Ogbeidu, 1991; Odum, 1992). Although the $\mathrm{pH}$ values recorded in Saba River was slightly alkaline during the period of study, it was within the recommended values of 6.6 and 8.5 by WHO (2011) and FEPA (2007). Statistical analyses however showed that the monthly mean $\mathrm{pH}$ values

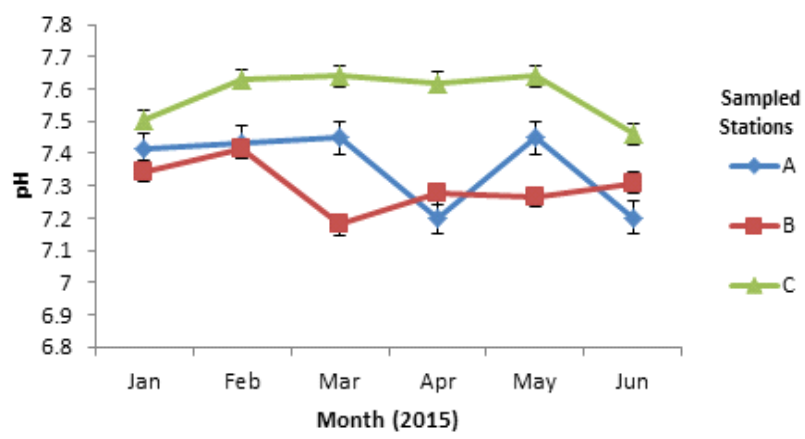

Fig. 4. The monthly mean variation of water $\mathrm{pH}$ of the water sampled from Saba River

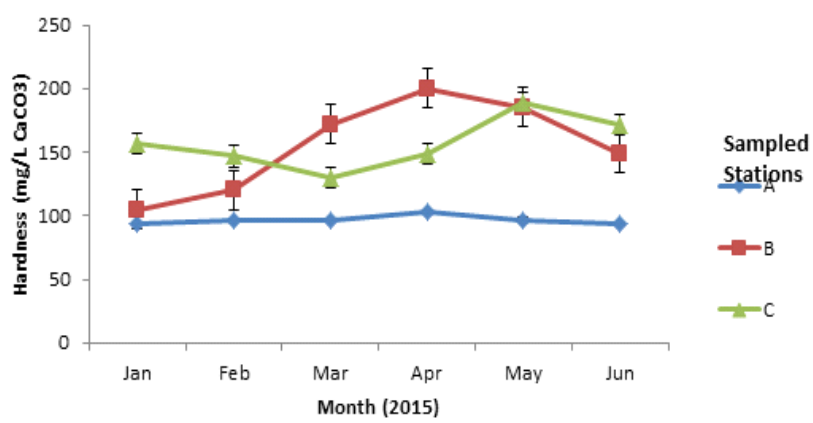

Fig. 5. The monthly mean variation in the total hardness $\left(\mathrm{mg} / \mathrm{L} \mathrm{CaCO}_{3}\right)$ of the water sampled from Saba River 
of the water sampled from sampling Stations A and B were not significantly different $(P>0.05)$ from each other, but were however significantly different $(\mathrm{P}<0.05)$ from station $\mathrm{C}$ pH (Table 2).

\section{Total hardness}

The total hardness values of the water recorded within the study period in Saba River which ranged between 93.62 $\mathrm{mg} / \mathrm{L} \mathrm{CaCO} 3$ and $200.33 \mathrm{mg} / \mathrm{L} \mathrm{CaCO} 3$ was above the desirable range of $50-150 \mathrm{mg} / \mathrm{L} \mathrm{CaCO} 3$ (Stone and Thomforde, 2004) but correlated with the values recorded by Lawson (2011) in the mangrove swamps of Lagos Lagoon. Higher values of total dissolved solid recorded in Station B and Station C, especially in April and March 2015 respectively, could probably be due to various activities around the sampled stations (Fig. 5). Such notable activities include dumping of wastes, utilisation of soaps and detergents in car wash and building construction around stations B and C. Heavy runoffs, as a result of early rainfall during these months, could also contribute to these higher values. Comparatively however, the total hardness of water sample collected from Station A was found to be significantly lower $(\mathrm{P}<0.05)$ than Stations B and C (Table 2).

\section{Acidity}

Acidity, which is the quantitative expression of water capacity to neutralize a strong base to a designated $\mathrm{pH}$ and an indicator of water corrosiveness (Hach, 1989), ranged during the study period between $11.0 \mathrm{mg} / \mathrm{L}$ and $81.0 \mathrm{mg} / \mathrm{L}$, with Station B having the highest value, while Station A had the lowest acidity. Although there is no documented reference or recommended acceptable limit for acidity in waterbodies (EPA, 2001), Longe and Ogundipe (2011) however reported that faecal droppings are known to increase organic level of water, which in turn leads to increasing acidity level. The highest acidity value in Station $B$ over the other stations could probably be due to the observed solid waste disposal practice as faecal dump was a prominent feature in the station's catchment area. Fig. 6 showed that there was a gradual increase in the monthly mean total acidity between January and April 2015, followed by a decline, with the lowest value recorded in June 2015. The increase in acidity level between these periods could be as a result of high temperature, which aids decomposition of organic wastes and decrease in water volume resulting in higher concentration of the nutrients. The total acidity was also significantly different $(\mathrm{P}<0.05)$ with respect to the sampling stations.

\section{Alkalinity}

Alkalinity values which ranged between 108 and 267 $\mathrm{mg} / \mathrm{L} \mathrm{CaCO} 3$ was recorded in Saba River during the sampling period (Fig. 7). The levels recorded in Station B and $\mathrm{C}$ between February and June were however higher than the prescribed acceptable limit of $120-170 \mathrm{mg} / \mathrm{L}$ for domestic use (WHO 2011), but fell within acceptable limit of $20-200 \mathrm{mg} / \mathrm{L}$ and 30 to $500 \mathrm{mg} / \mathrm{L}$ for fish and shrimp production (Abowei and George, 2010). Comparative analyses showed that the mean alkalinity values between the sampling stations were significantly different $(P<0.05)$ during the period of study (Table 2).

\section{Dissolved Oxygen}

The dissolved Oxygen (DO) values recorded in water samples collected from Saba River during the study period which ranged between $2.0 \mathrm{mg} / \mathrm{L}$ to $12.6 \mathrm{mg} / \mathrm{L}$ was similar

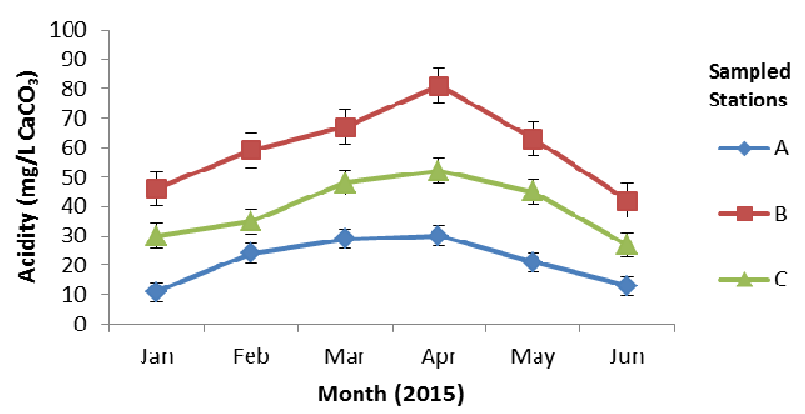

Fig. 6. The monthly mean variation in the acidity $(\mathrm{mg} / \mathrm{L}$ $\mathrm{CaCO}_{3}$ ) of the water sampled from Saba River

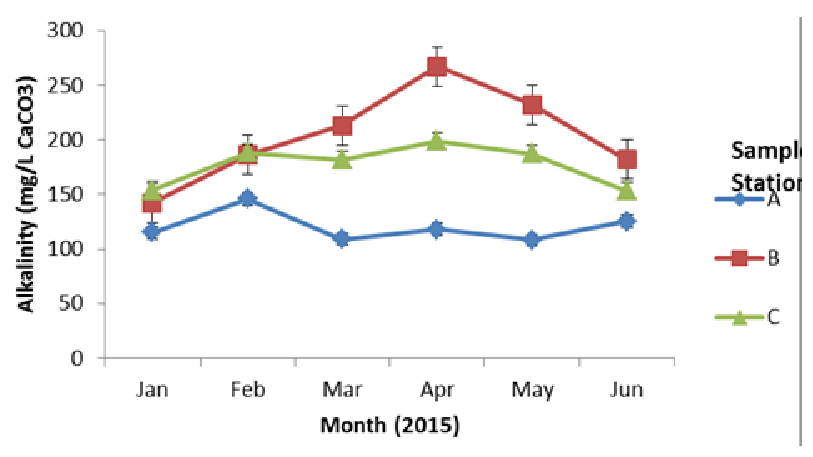

Fig. 7. The monthly mean variation in the alkalinity $(\mathrm{mg} / \mathrm{L}$ $\mathrm{CaCO}_{3}$ ) of the water sampled from Saba River

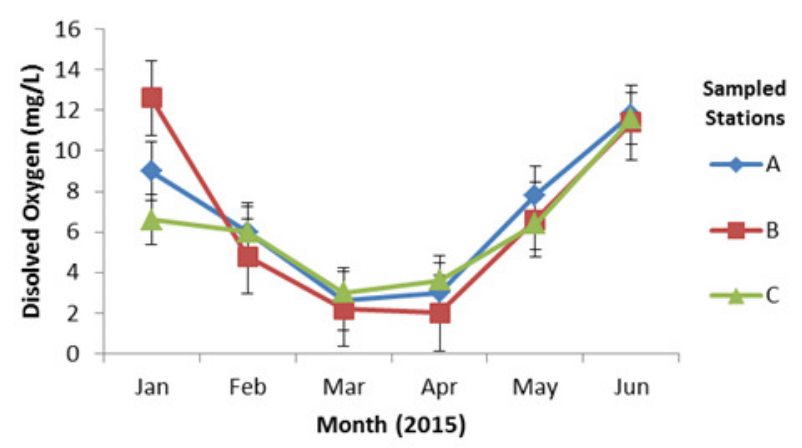

Fig. 8. The monthly mean variation in the dissolved oxygen $(\mathrm{mg} / \mathrm{L})$ level of the water sampled from Saba River

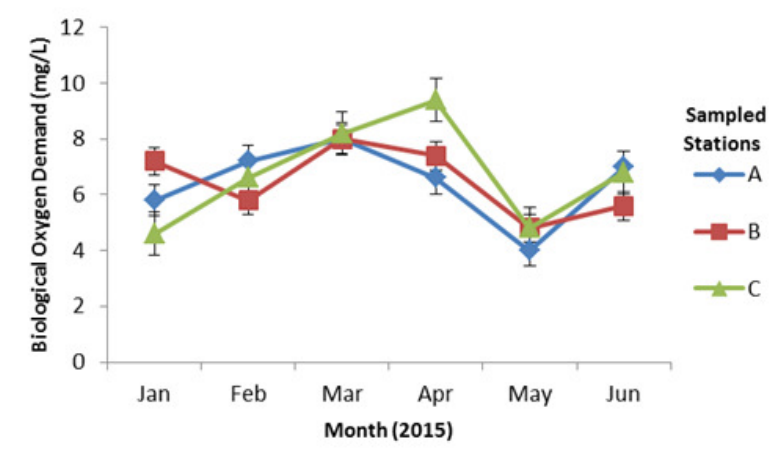

Fig. 9. The monthly mean variation in the biological oxygen demand $(\mathrm{mg} / \mathrm{L})$ of the water sampled from Saba River 
192

to those reported for many other polluted Nigerian waters (Victor and Onmivbori, 1996; Edokpayi and Osimen, 2001; Ogunwenmo and Kusemiju, 2004; Deekay et al., 2010). The high organic content from human faeces, decayed plant materials and domestic wastes dumped into the River could probably be responsible for the low dissolved oxygen recorded in March and April, 2015 across all the sampled stations. Even more, the high DO value recorded in June (Fig. 8) could probably be due to early rainfall which has led to the increase in water volume, turbulence and increased dissolution of oxygen at air-water interphase. The difference in the mean dissolved oxygen levels of the sampled stations during the period of study were, however, statistically insignificant $(\mathrm{P}>0.05)$ (Table 2$)$.

\section{Biological Oxygen Demand $\left(B O D_{5}\right)$}

BOD5 has been classified based on fair measure of cleanliness of any water such that values less than $2 \mathrm{mg} / \mathrm{L}$ are clean, 3-5 mg/L fairly clean, while water body with 10 $\mathrm{mg} / \mathrm{L}$ and above value is definitely bad and polluted (Clerk, 1986; Bhatnagar and Singh, 2010; Ekubo and Abowei, 2011). The BOD5 values obtained from the various sampled stations which ranged between 4.0 and $9.4 \mathrm{mg} / \mathrm{L}$ are an indication of the level of pollution in Saba River, which could be classified as fairly polluted. In spite of the variations in the monthly mean BOD5 across the stations (Fig. 9), the recorded means were not statistically different $(\mathrm{P}>0.05)$ (Table 2).

\section{Chemical Oxygen Demand (COD)}

According to Ogunfowokan et al. (2005), an increase in COD could be attributed to increase in addition of both organic and inorganic substances from the environment, as well as organic contaminant entering water systems. Water from Saba River with COD values ranging from 14.95 $\mathrm{mg} / \mathrm{L}$ to $31.47 \mathrm{mg} / \mathrm{L}$ fell within the acceptable limit of 20 $60 \mathrm{mg} / \mathrm{L}$ of EPA (2001) and WHO (2011). Similar pattern of COD values was recorded in all the sampled stations with the peak COD value recorded in April, 2015 (Fig. 10). Statistical analysis showed that there were no significant differences $(P>0.05)$ in the COD values of water samples collected from Stations A and C, but the mean COD values from both stations were significantly different $(P<0.05)$ from those of Station B (Table 2).

\section{Phosphate}

The phosphate values of Saba River during the period of study ranged from $1.98 \mathrm{mg} / \mathrm{L}$ to $3.77 \mathrm{mg} / \mathrm{L}$ which is indicative of a moderately polluted environment as phosphate values of between $40 \mathrm{mg} / \mathrm{L}$ to $120 \mathrm{mg} / \mathrm{L}$ is considered high and can lead to environmental pollution (Ajibade et al., 2008). Although, the recorded phosphate values were relatively low, Station $B$ recorded the highest values of phosphate content in March and April (Fig. 11) during the period of study.

Despite the higher concentrations of phosphate at station B which could be due to the discharges of refuse rich in phosphate ions, the river could still be considered healthy because the levels of nutrients for unhealthy aquatic ecosystems approximately $5 \mathrm{mg} / \mathrm{L}$ of $\mathrm{P}$ as orthophosphate and organophosphate (Limbu and Kyevalyanga, 2015). This level is still higher compared to highest concentrations

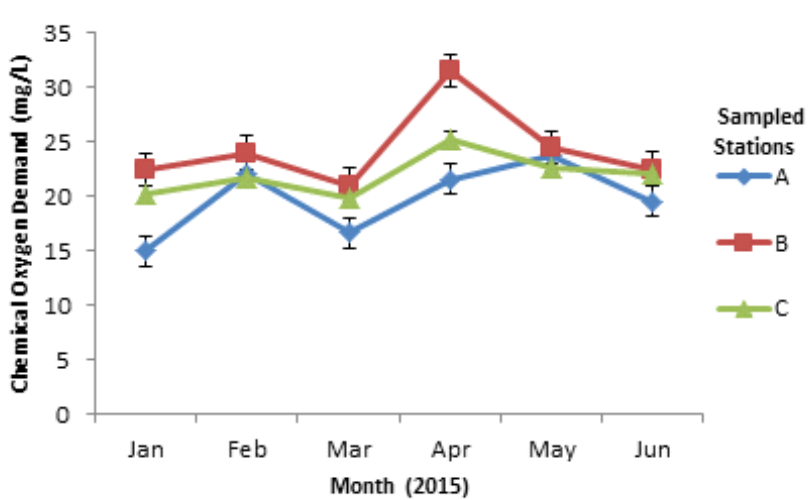

Fig. 10. The monthly mean variation in the chemical oxygen demand $(\mathrm{mg} / \mathrm{L})$ of the water sampled from Saba River

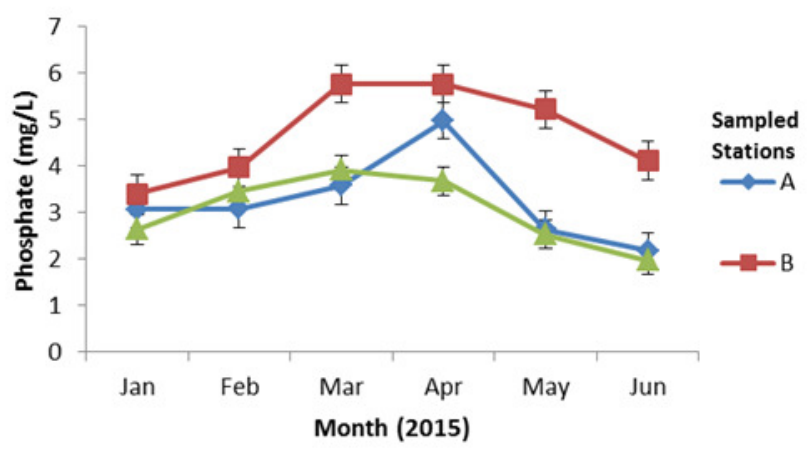

Fig. 11. The monthly mean variation in the phosphate $(\mathrm{mg} / \mathrm{L})$ levels of the water sampled from Saba River

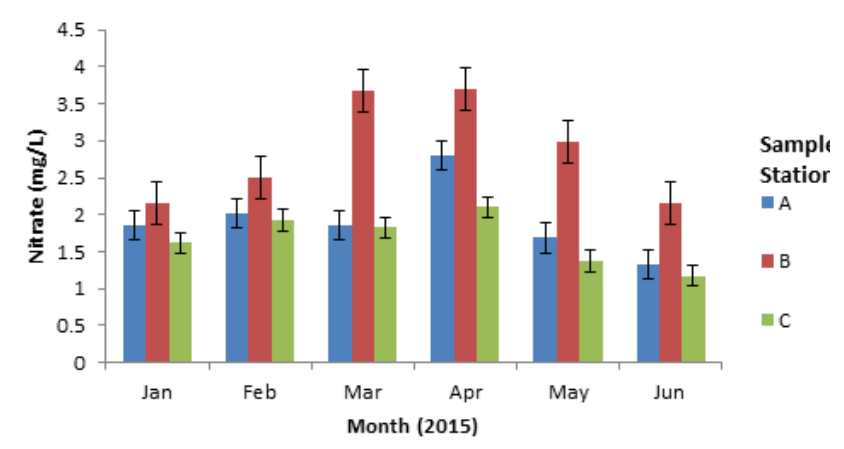

Fig. 12. The monthly mean variation in the nitrate $(\mathrm{mg} / \mathrm{L})$ levels of the water sampled from Saba River

of $3.77 \mathrm{mg} / \mathrm{L}$ for phosphate recorded in this study. However, release of nutrients in the study area should be limited to avoid excessive growth of phytoplankton and macroalgae, or even development of harmful algal blooms (HBAs) in the case of phytoplankton.

However, the general trend in all the sampled stations was that the phosphate content increases from January 2015 reaching the peak around March/April 2015 before declining gradually till June 2015 (Fig. 11), which may be due to the dilution of the phosphate content as a result of heavy rainfall and runoffs of surrounding water. There was no significant difference $(P>0.05)$ in the phosphate content of sampled station A and C; however, the phosphate contents of the two stations were significantly different $(\mathrm{P}<0.05)$ from that Station B (Table 2). 
Nitrate

The nitrate concentration of Saba River during the period of study was in the range of 1.175 to $3.690 \mathrm{mg} / \mathrm{L}$ (Fig. 12) which was below WHO (2003) guideline value of $50 \mathrm{mg} / \mathrm{L}$. This value was even low compared to the values of $37.25 \mathrm{mg} / \mathrm{L}$ and $43.89 \mathrm{mg} / \mathrm{L}$ reported by Igbinosa et al. (2012) in Shanomi creek, Niger Delta, Nigeria. The low values of nitrate recorded in Saba River during the study period showed that the river was mildly polluted with nitrogen pollutants. Statistical analysis showed no significant differences $(\mathrm{P}>0.05)$ between the mean nitrate levels of samples collected from Stations A and C, however, the nitrate concentration of samples from Station B was significantly higher $(\mathrm{P}<0.05)$ than those from both sampled Stations A and C (Table 2).

\section{Heavy metals}

\section{Cadmium}

Cadmium concentration in Saba River during the period of study which recorded a mean monthly range value of 0.0145 and $0.0385 \mathrm{mg} / \mathrm{L}$ was above the acceptable limit of $0.005 \mathrm{mg} / \mathrm{L}$ of EPA (ATSDR, 1999) and $0.003 \mathrm{mg} / \mathrm{L}$ of WHO and FEPA for potable water (WHO, 1984 and FEPA, 2007). The concentration of cadmium in Saba River was higher in Station B and C, but lower in Station A. These higher values of cadmium in the water samples from stations $\mathrm{B}$ and $\mathrm{C}$ could be attributed to various anthropogenic activities especially dumping of wastes into the river while station $\mathrm{A}$, which is close to the river source is almost devoid of pollution. Also, few meters before Station $\mathrm{B}$, there is a mechanic workshop from where runoff of battery waste waters, engine oil and other hydrocarbon byproducts is inevitable. Irrespective of the sampled points, highest Cadmium concentration was recorded in March 2015 (Fig. 13) with a gradual decline during the subsequent months. This increase in cadmium concentrations from January to March could probably be attributed to decrease in volume of the water and increase in temperature.

\section{Lead}

Lead concentration in Saba River with monthly mean range of $0.0070 \mathrm{mg} / \mathrm{L}$ to $0.0335 \mathrm{mg} / \mathrm{L}$ was similar to lead concentration reported by Dike et al. (2004) in River Jakara, Kano State and is above the acceptable limit in potable

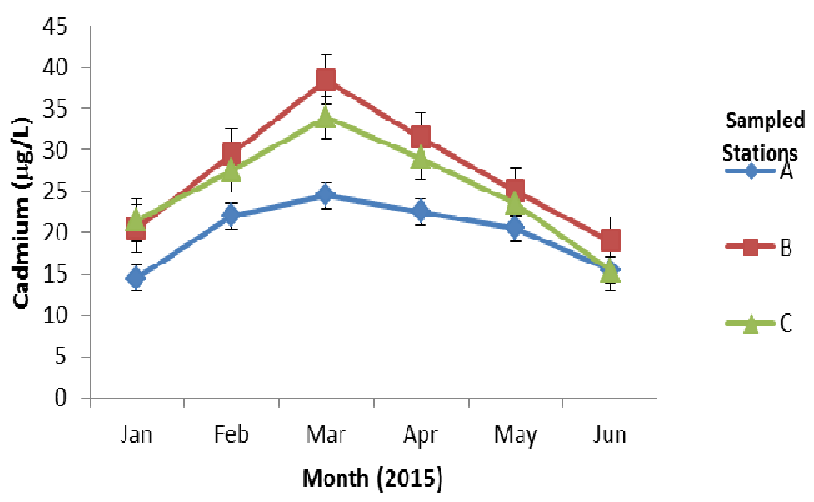

Fig. 13. The monthly mean variation in the cadmium $(\mathrm{mg} / \mathrm{L})$ levels of the water sampled from Saba River

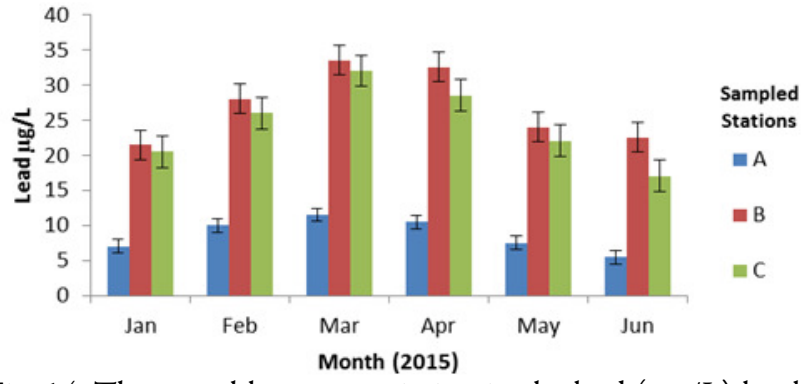

Fig. 14. The monthly mean variation in the lead $(\mathrm{mg} / \mathrm{L})$ levels of the water sampled from Saba River

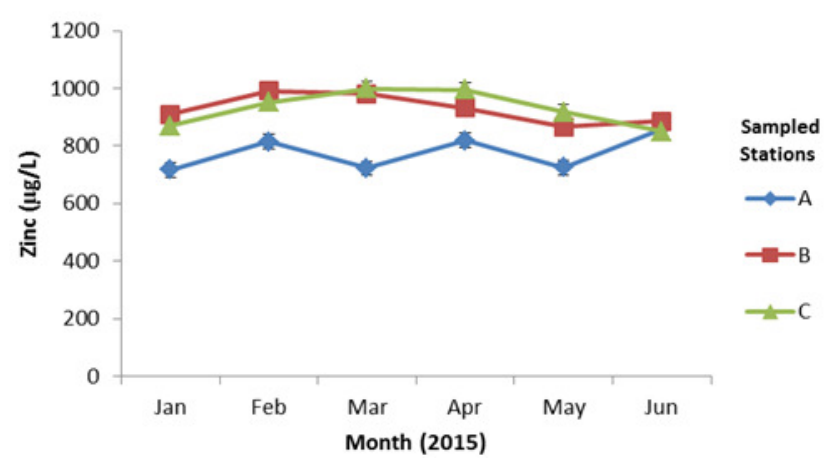

Fig. 15. The monthly mean variation in the Zinc (mg/L) levels of the water

water of $0.02 \mathrm{mg} / \mathrm{L}$ (WHO, 1996 and FEPA, 2007). The lead concentrations values were also significantly higher in Stations B and C than in Station A (Fig. 14). This may also be due to direct release of domestic waste containing lead form anthropogenic activities in these stations catchment area that could have led to increase in lead concentrations. General comparative analysis of lead concentrations amongst the sampled stations showed no statistically significant difference $(\mathrm{P}>0.05)$ (Table 2$)$.

\section{Zinc}

Zinc concentration in Saba River recorded a monthly mean range of 0.717 to $1.00 \mathrm{mg} / \mathrm{L}$ which is below the acceptable limit for potable water of $5 \mathrm{mg} / \mathrm{L}$ (WHO 2011). Although the values of zinc concentrations in Saba River during the period of study was generally low compared to acceptable limits of $5 \mathrm{mg} / \mathrm{L}$ (WHO, 2011), the recorded values were higher in Stations B and C, which could also be as a result of pollution and lower in station A (Fig. 15). Higher value of the element in Stations B and C could probably be attributed to pollution effects downstream. Zinc is required in the body in trace amount as it helps balance copper in the body, and is essential for male reproductive activity (Nolan, 2003), while also serving as a co-factor for dehydrogenating enzymes and in carbonic anhydrase (Holum, 1983). Zinc deficiency causes anaemia and retardation of growth and development (McCluggage, 1991). Hence, the recorded low concentration of zinc could have made the river suitable for consumption, but was noted the higher level of other heavy-metals. Comparative analysis in the level of zinc between the sampled stations showed no significant differences $(\mathrm{P}>0.05)$ between Stations B and $\mathrm{C}$ which were however significantly higher than Station A $(\mathrm{P}<0.05)$ (Table 2). 
194

\section{Conclusions}

The assessment of the water quality revealed that most of the physicochemical parameters determined were within the minimum and maximum allowable limits with the exception of some oxygen parameters (DO, BOD and COD), which showed a level of pollution in the river. Cadmium and Lead concentration values were also found to be above acceptable limits of WHO and FEPA. However, the concentration of zinc well within the acceptable range could be a source of zinc supply to the body even though the water is not safe for consumption unless treated. Across the stations, the physico-chemical parameters of Saba River revealed that most of the parameters assessed were higher in Stations B and C compared to Station A which was closer to the river source.

\section{References}

Abowei JF, George AD (2010). The morphology, abundance, size and sex distribution of Callinectes amnicola (DeRochebrune, 1883) from Okpoka Creek, Niger Delta, Nigeria. Current Research Journal of Biological Sciences 2(1):27-34.

Ademoroti CM (1996). Environmental chemistry and toxicology, Foludex Press Ltd, Ibadan pp 171-204.

Ajibade WA, Ayodele IA, Agbede SA (2008). Water quality in the major rivers of Kainji lake National Park, Nigeria. African Journal of Environmental Sciences and Technology 2(7):185-196.

Ali LA (2007). A study of macro-invertebrates community in the middle sector of greater Zab River, Iraq. PhD Thesis, University of Baghdad, Iraq.

APHA, (American Public Health Association), AWWA (American Water Works Association), WPCF (Water Pollution Control Facilities) (1992). Standard Methods for the Examination of Water and Wastewater, $18^{\text {th }}$ Ed. American Public Health Association Washington DC: 1289.

ATSDR (Agency for Toxic Substances and Disease Registry) (1989). Toxicological profile for chromium. Washington DC, US Public Health Service (ATSFDR/TP 88/10).

Ayodele IA, Ajani EK (1999). Essentials of fish farming (aquaculture). Published by Oduduwa Printing Works, Ibadan, Nigeria pp 47.

Bhatnagar A, Singh G (2010). Culture fisheries in village ponds: A multi-location study in Haryana, India. Agriculture and Biology Journal of North America 1(5):961-968.

Chapman D, Kimstach V (1996). Water quality assessment-A Guide to use of biota, sediments and water in environmental monitoring. 2nd Edition. Edited by Deborah Chapman pp 45.

Clerk RB (1986). Marine Pollution. Clarandon Press, Oxford.

Deekay SN, Abowei JFN, Alfred-Ochiya JF (2010). Seasonal variation of some physical and chemical parameters of Luubara Creek, Ogoni Land, Nigeria. Research Journal of Environmental and Earth Sciences 2(4):208-215.

Dike, NI, Ezealor, AU, Oniye SJ (2004). Concentration of Pb, Cu, Fe and Cd during the dry season in River Jakara, Kano, Nigeria. Chemical Class Journal 1:78-81.
Duruibe JO, Ogwuegbu MOC, Egwurugwu JN (2007). Heavy metal pollution and human bio-toxic effects. International Journal of Physical Sciences 2(5):112-118.

Edokpayi CA, Osimen EC (2001). Hydrobiological studies on Ibiekuma River at Ekpoma, Southern Nigeria, after impoundment: The fauna characteristics. African Journal of Science and Technology 2(1):72-81.

Ekpo KE, Asia IO, Amayo KO, Jegede DA (2008). Determination of Lead, Cadmium and Mercury in surrounding water and organs of some species of fish from Ikpoba River in Benin City, Nigeria. International Journal of Physical Sciences 3(11):289-292.

Ekubo AT, Abowei JFN (2011). Review of some water quality management principles in culture fisheries. Research Journal of Applied Sciences, Engineering and Technology 3(12):1342-1357.

FEPA (Federal Environmental Protection Agency) (2007). Guidelines and standards for environmental pollution control in Nigeria.

Galadima A, Garba ZN, Leke L, Almustapha MN, Adam IK (2011). Domestic water pollution among local communities in NigeriaCauses and consequences. European Journal of Scientific Research 52(4):592-603.

Golterman HL, Clymo RS, Ohnstad MAM (1978). Methods for physical and chemical analysis of freshwater. Blackwell Science Publication Oxford, Edinburgh, London, Melbourne.

Gulson BL, Sheehan A, Giblin AM, Chiaradia M, Conradt B (1997). The efficiency of removal of lead and other elements from domestic drinking waters using a bench-top water filter system. Science Total Environment 196:205-216.

Hach Company (1989). Hach water analysis handbook. Hach Company, Loveland, USA, Colorado pp 19-20.

Holum JR (1983). Elements of general and biological chemistry $6^{\text {th }}$ Edition, John Wiley and Sons, New York pp 324, 326, 353, 469.

Igbinosa EO, Uyi, OO, Odjadjare EE, Ajuzie CU, Orhue PO, Adewole EM (2012). Assessment of physicochemical qualities, heavy metal concentrations and bacterial pathogens in Shanomi Creek in the Niger Delta, Nigeria. African Journal of Environmental Science and Technology 6(11):419-424.

INECAR (Institute of Environmental Conservation and Research) (2000). Position paper against mining in Rapu-Rapu. Published by INECAR, Ateneo de Naga University, Philippines (www. adnu.edu.ph/Institutes/Inecar/pospaper1.asp).

Kamran TM, Abdus S, Muhammed L, Tasveer Z (2003). Study of the seasonal variations in the physicochemical and biological aspects of Idus River, Pakistan. Pakistan Journal of Biological Sciences 6(21):1795-1801.

Lawson EO (2011). Physico-chemical parameters and heavy contents of water from the Mangrove Swamps of Lagos Lagoon, Lagos, Nigeria. Advances in Biological Research 5(1):8-21.

Limbu SM, Kyewalyanga MS (2015). Spatial and temporal variations in environmental variables in relation to phytoplankton composition and biomass in coral reef areas around Unguja, Zanzibar, Tanzania. Springer Open Journal 4:646-664.

Longe EO, Ogundipe AO (2010). Assessment of wastewater discharge 
impact from a sewage treatment plant on Lagoon Water, Lagos, Nigeria. Research Journal of Applied Sciences, Engineering and Technology 2(3): 274-282.

Matthews A, Omono C, Kakulu S (2012). Physico-chemical parameters and heavy metals in River Pompom in Okehi Local Government Area of Kogi State, Nigeria. International Research Journal of Biotechnology 3(8):134-140.

McCluggage D (1991). Heavy metal poisoning, NCS Magazine, Published by The Bird Hospital, Columbus, USA.

McNeely RN, Neimanis VP, Dwyer L (1979). Water quality sources - a guide to water quality parameters. Publisher and Country.

Morrison G, Fatoki OS, Ekberg A (2001). Assessment of the impact of point source pollution from the Keiskammahoek sewage treatment plant on the Keiskamma River. Water South Africa 27(4):475-480.

Neal C (2001). Alkalinity measurements within natural waters: towards a standardized approach. Science and Total Environment 265:99113.

Nnduka JK, Orish EO, Linus OE (2008). Some physico-chemical parameters of potable water supply in Warri, Niger Delta Area of Nigeria. Scientific Research and Essay 3(11):547-551.

Nolan K (2003). Copper toxicity syndrome. Journal of Orthomology and Psychiatry 12(4):270-282.

Odum O (1992). The Fish Communities of Ethiope River, Nigeria. PhD Thesis, University of Benin, Benin City.

Ogbeidu AE (1991). Hydrological characteristics of waterbodies in the Okomu Forest Reserve (Sanctuary), Benin City, Nigeria PhD Thesis, University of Benin, Benin City, Nigeria.

Ogunfowokan AO, Okoh EK, Adenuga AA, Asubiojo OI (2005). An assessment of the impact of point source pollution from a university sewage treatment oxidation pond on a receiving stream - A preliminary study. Journal of Applied Sciences 5(1):36-43.

Ogunwenmo CA, Kusemiju K (2004). Annelids of a West African estuarine system. Journal of Environmental Biology 25(2):227-237.

Onwudinjo CC (1990). The hydrological and plankton of Benin River, Nigeria. PhD Thesis, University of Benin, Benin City, Nigeria.

Papadopoulous ME, Karpouzas DG, Patsias J, Kotopoulou A, Kintzikoglou K, Vlachou P (2004). The potential of pesticides to contaminate the groundwater resources of the Axios River Basin in Macedonia, Northern Greece. Part 1. Monitoring Study in the North Part of the Basin. Total Environment 3(21):127-146.

Park JK, Wang J, Novotny G (1997). Wastewater characterisation for evaluation of biological phosphorus removal: Wastewater fractionation. WDNR research report 174, Wisconsin Dept. of Natural Resources, Wisconsin-Madison, USA.
Peretiemo-Clarke BO, Balogun MA, Akpojiyovwi O (2009). A study of physico-chemical characteristics of Ugborikoko/Okere stream as an index of pollution. African Journal of Biotechnology 8:6272-6276.

Revelle P, Revelle C (1988). The Environment issues and choices for Society: Oston, Jones and Bartlett.

Sawyer GN, McCarty DL (1967). Chemistry of Sanitary Engineers, 2ndEd. McGraw Hill, New York pp 4-15.

Shektia YA (2008). The effect of erbil city wastewater discharge on water quality of greater $\mathrm{Zab}$ River and the risks of irrigation. $\mathrm{PhD}$ Thesis, University of Baghdad, Iraq.

Solis NB (1988). The biology and culture of Penaeus Monodon, Department Papers. SEAFDEC Aquaculture Department, Tigbouan, Boilo Philippines pp 3-36.

SON (2007). Standard Organization of Nigeria, Nigerian Standard for drinking water quality pp 15-16.

Sterrit RM, Lester JN (1998). Environmental microbiology: microbiology for environmental and public health engineers. New York pp 9-11.

Stone NM, Thomforde HK (2005). Understanding your fish pond: Water analysis report. Retrieved 2016 Oct from http: //www.uaex.edu/wneal/pond_management/pdf/FSA9090.pdf

UNEP/WHO (1996). Water quality monitoring - a practical guide to the design and implementation of freshwater quality studies and monitoring programmes. Published on behalf of United Nations Environment Programme and the World Health Organization. ISBN 0419223207 (Hbk) 0419217304 (Pbk).

USEPA (2000). National primary drinking water regulations. United States Environmental Protection Agency.

Victor R, Onomivbori O (1996). The effects of perturbation on the benthic macroinvertebrates of a Southern Nigeria stream. SPB Academic Publishing, Amsterdam, The Netherlands pp 223-238.

WHO (1984). Guidelines for drink water quality. Vol. I: Recommendations, WHO, Geneva pp 193-199.

WHO (2003). Guidelines for drinking water quality, Health Criteria and Other Supporting Information 2nd Ed, Vol 2.

WHO (2011). Manganese in drinking water. Background document for development of WHO Guidelines for Drinking-water Quality. 